\title{
Kajian:
}

\section{PROSES REKRUTMEN CALON LEGISLATIF OLEH PARTAI POLITIK DI KABUPATEN LABUHANBATU PADA PEMILU 17 APRIL 2019 (STUDI KASUS PDIP, NASDEM, PKS, PAN)}

\author{
Fenni Pidia Wati ${ }^{1}$, Khairul Fahmi Lubis ${ }^{2}$ \\ Program Studi Pendidikan Pancasila dan Kewarganegaraan \\ STKIP Labuhanbatu, Jl.SM Raja No126 A, Rantauprapat
}

email: fennipidia68@gmail.com,khairulfahmilubis@gmail.com

\begin{abstract}
Abstrak
Penelitian ini bertujuan untuk mengetahui proses rekrutmen calon legislatif oleh partai politik di Kabupaten Labuhanbatu pada pemilu 17 April 2019 yang dilakukan oleh partai PDIP, NASDEM, PKS, PAN sesuai dengan mekanisme rekrutmen terbuka atau tertutup. Penelitian ini menggunakan jenis penelitian kualitatif dengan pendekatan deskriptif. Informan dalam penelitian ini adalah KPU Kabupaten Labuhanbatu, Ketua Partai Demokrasi Indonesia Perjuangan, Ketua Partai Nasional Demokrat, Ketua Partai Keadilan Sejahtera, Ketua Partai Amanat Nasional. Teknik pengumpulan data yang digunakan peneliti yaitu dengan cara wawancara, dan studi dokumentasi. Hasil penelitian ini menunjukkan bahwa : Dari data calon tetap yang peneliti peroleh dari masing-masing partai politik di Kabupaten Labuhanbatau diperoleh jumlah daftar calon tetap Partai Demokrasi Indonesia Pejuangan sebanyak 45, Partai Nasional Demokrat Sebanyak 45, Partai Keadilan Sejahtera 40 dan Partai Amanat Nasional sebanyak 40 . Proses rekrutmen calon legislatif yang dilakukan oleh masing-masing partai politik melalui rekrutmen secara terbuka. Bentuk pelaksanaan syarat rekrutmen pada pemilu 17 April 2019 yang dilakukan oleh masing-masing partai politik mengacu dalam ketentuan Peraturan komisi pemilihan umum Nomor 20 tahun 2018. Dari penelitian yang telah dilakukan bahwah sifat rekrutmen yang di lakukan oleh partai PDIP, NASDEM, PKS, PAN melalui sifat rekrutmen secara bottom-up. Bentuk penetapan calon legislatif masing-masing partai politik memiliki perbedaan, Partai Demokrasi Indonesia Perjuangan (PDIP) dalam menentukan penetapan calon legislatif diutamakan dari struktural partai yang ada di peratutan partai demokrasi indonesia perjuangan Nomor 25-A Tahun 2018 pasal 28 ayat 1 ketua, sekretaris, bendahara wajib nomor 1, sedangkan NASDEM dalam penetapannya menentukannya dari loyalitas calon legislatif artinya bagaimana pengabdian ke partai politik, keaktifan di berbagai kegiatan dan loyalitas yang diprioritaskan pada nomor urut atas, sedangkan PKS menentukan berdasarkan kewenangan dari partai itu yang menentukan dilihat dari keaktifan selama di partai politik, dan PAN menentukan penetapan calon legislatif sesuai dengan hasil dari skoring yang di lakukan oleh KPPD (Komite Pemenangan Pemilu Daerah).
\end{abstract}

Kata Kunci: Rekrutmen, Partai Politik, Calon Legislatif 


\section{Kajian:}

\section{Pembelajaran PPKn}

\section{PENDAHULUAN}

Pemilu pada tahun 2019 merupakan pemilu yang dilakukan secara serentak yang meliputi pemilihan Presiden dan wakilnya, anggota perwakilan mulai dari Dewan Perwakilan Rakyat Republik Indonesia, Dewan Perwakilan Rakyat Daerah Provinsi dan Kabupaten / kota, dan Dewan Perwakilan Daerah. Adapun jumlah peserta partai pemilu pada tahun 2019 diikuti oleh 20 partai politik yang terdiri dari, 16 partai politik nasional dan 4 partai politik lokal, yang dinyatakan lulus verifikasi faktual dan lolos sebagai peserta pemilu oleh Komisi Pemilihan Umum (KPU).

Namun, kenyataanya yang terjadi di Kabupaten Labuhanbatu sendiri partai politik merekrut figur-figur yang sebenarnya memiliki latar belakang yang kurang paham dari dunia politik, seharusnya partai politik merekrut para calon legislatif yang telah menjadi kader dari partai. Dilihat dari calon-calon legislatitf yang muncul sebagian diambil dari para tokoh. JOMAS Vol. 1 No. 1 Januari (2019) Hal : 1 - 6

agama, tokoh perempuan, tokoh kepemudaan, tokoh organisasi, dan pengusaha. Dengan munculnya caloncalon legislatif yang kurang mempunyai latar belakang dan pengalaman yang memenuhi membuat parah calon legislatif dengan mudahnya memberikan money politik terhadap masyarakat dengan membeli suaranya. Sehingga tidak adanya komitmen dari calon legislatif untuk berjuang menyuarakan aspirasi rakyat.
Realita yang terjadi terhadap kinerja anggota legislatif tidak sepenuhnya memberikan dampak bagi masyarakat.

Terkait dengan jalannya pemerintah daerah, rekrutmen calon legislatif memiliki peran yang sangat menentukan. Oleh karena itu partai politik sangat bertanggung jawab dalam mempersiapkan individu-individu yang mampu, mau dan berkompeten menjadi anggota legislatif.

Dengan melihat permasalah yang telah diuraikan diatas, peneliti akan menganalis bagaimana peranan rekrutmen politik di Partai Demokrasi Indonesia Perjuangan dan Partai Nasional Demokrat menentukan partisipasi masyarakat untuk memilih khususnya di Kabupaten LabuhanBatu, dengan ini maka peneliti tertarik untuk melakukan penelitian dengan judul "Proses Rekrutmen Calon Legislatif Oleh partai politik di Kabupaten LabuhanBatu Pada Pemilu 17 April 2019 (Studi Kasus PDIP, NASDEM, PKS, PAN).

\section{Pengertian Partai Politik}

Menurut Assiddiqie dalam Labolo (2017) Pengertian partai politik secara etimologis berasal dari kata part yang berarti bagian atau golongan. Kata partai menunjuk pada golongan sebagai pengelompokan masyarakat berdasarkan kesamaan tertentu seperti tujuan, ideologi, agama, atau bahkan kepentingan.

Berdasarkan pendapat diatas dapat disimpulkan bahwa partai politik merupakan suatu kelompok atau organisai yang mempunyai tujuan untuk 


\section{Kajian: \\ Pembelajaran PPKn}

mewujudkan suatu visi, misi, dan program yang ada di partai politik untuk menduduki suatu jabatan.

\section{Adapun Fungsi Partai Politik}

a. Sebagai wadah penyampaian aspirasi oleh masyarat bawah kepada lembaga pemerintah melalui partai politik

b. Rekrutmen kekuasaan melalui jalur partai politik untuk mengisi jabatan.

\section{Pengertian Rekrutmen Politik}

Rizki karunia dwi (2017) dalam jurnal Pola Rekrutmen Partai Nasional Demokrat Pada Pencalonan Anggota Legislatif Tahun 2014 Kabupaten Jombang mengatakan bahwa Rekruitmen politik adalah merupakan suatu kunci dari keberhasilan sistem politik di negara, karena dalam fase ini membutuhkan suatu proses untuk menentukan orang-orang atau individu yang akan menjalankan fungsi sistem politik negara itu baik melaui lembaga-lembaga yang ada. Rekrutmen politik pada dasarnya bersifat menyeleksi untuk menduduki jabatan yang ada di pemerintahan atau lembaga dengan proses yang menentukan berdasarkan kemampuan.

Dalam proses rekrutmen ada dua mekanisme rekrutmen politik yaitu rekrutmen terbuka dan rekrutmen tertutup. Rekrutmen Terbuka, adalah suatu proses yang dilalukan secara umum untuk mengisi kedudukan atau jabatan baik itu di lembaga atau pemerintah berdasarkan kualitas dan kemampuan. Sedangkan Rekrutmen Tertutup, adalah JOMAS Vol. 1 No. 1 Januari (2019)Hal : $1-6$ proses pelaksanaan Kesempatan yang hanya dinikmati oleh sekelompok orang yang

mempunyai kedekatan pada pimpinan elit politik.

Dari penjabaran diatas, dapat disimpulkan bahwa Rekrutmen politik adalah suatu proses seleksi dimana individu-individu atau kelompok memenuhi kriteria untuk menduduki pada jabatan-jabatan di lembaga politik. Rekrutmen politik sangat berpengaruh bagaimana kualitas seseorang yang memang sudah dipersiapkan untuk menjadi anggota legislatif.

\section{Sifat Rekrutmen Politik}

a. Top-down, adalah proses rekrutmen politik yang dilakukan bersifat direkomendasikan oleh orang-orang yang menjabat atau yang telah direkomendasikan oleh pimpinan partai politik.

b. Bottom-up, adalah proses rekrutmen politik yang berasal dari masyarakat bawah, dalam artian rekrutmen ini dilakukan melalui penjaringan tim seleksi yang ada di partai politik.

c. Bersifat campuran, adalah rekrutmen yang dilakukan pertama kali di tingkat atas sampai bawah dan sebaliknya rekrutmen dilakukan di tingkat bawah sampai atas. rekrutmen ini biasanya dipakai pada saat pemilihan eksekutif.

\section{Kerangka Konseptual}

Pemilihan umum merupakan tempat pemilihan seseorang untuk menduduki suatu jabatan yang ada di 


\begin{abstract}
Kajian:
Pembelajaran PPKn

pemerintahan. Salah satu bentuk dari pemilihan umum tersebut adalah pemilahan umum legislatif. Pemilihan umum legislatif ini bertujuan untuk mencari perwakilan masyarakat di pemerintahan atau yang biasa disebut dengan anggota dewan perwakilan rakyat.Pemilihan yang berlangsung lima tahun sekali ini sangat menentukan terwujudnya kedaulatan rakyat secara maksimal. Partai politik mempunyai peran yang besar dalam menghasilkan wakil rakyat yang berkualitas
\end{abstract}

\section{METODE PENELITIAN}

\section{a. Tempat dan Waktu Penelitian}

Adapun tempat Penelitian yang dilaksanakan di Kabupaten Labuhanbatu meliputi Partai Demokrasi Indonesia Perjuangan, Partai Nasional Demokrat, Partai Keadilan Sejahtera, Partai Amanat Nasional dan waktu penelitian yang dilaksanakan pada bulan Februari sampai bulan Juni 2019.

\section{b. Pendekatan dan Jenis Penelitian}

Peneliti menggunakan Jenis penelitian kualitatif dengan pendekatan deskriptif.

Peneliti memilih jenis penelitian ini karena peneliti bermaksud untuk menjelaskan dan mendeskripsikan masalah yang diteliti sehingga tergambar jelas bagaimana proses rekrutmen calon legislatif melalui partai politik pada wilayah Kabupaten Labuhanbatu, khususnya calon legislatif pada Partai Demokrasi Indonesia Perjuangan (PDIP),
Partai Nasional Demokrat (NASDEM), Partai Keadilan Sejahtera (PKS), Partai Amanat Nasional (PAN).

\section{c. Sumber Data}

Sugiyono (2014) sumber data utama dalam penelitian ini manusia sebagai peneliti, memilih informan sebagai sumber data. Sumber data merupakan tempat diperoleh data ataupun dokumendokumen. Jenis data yang dikumpulkan melalui penelitian ini meliputi sumber data primer dan data sekunder.

\section{d. Data Primer}

adalah data yang diperoleh langsung dari sumbernya. Sumber data primer yang digunakan dalam penelitian ini meliputi: Informan dari pihak Wakil Ketua Bidang Pemenangan Pemilu \& Komunikasi politik Partai Demokrasi Indonesia JOMAS Vol. 1 No. 1 Januari (2019)Hal : $1-6$

Perjuangan Kabupaten Labuhanbatu, Sekretaris Partai Nasional Demokrat Kabupaten Labuhanbatu, Ketua Umum Partai Keadilan Sejahtera Kabupaten Labuhanbatu, dan Wakil Ketua Partai Amanat Nasional Kabupaten Labuhanbatu.

\section{e. Data Sekunder}

Data yang diperoleh bukan secara langsung dari sumbernya. Penelitian ini yang dipakai adalah sumber tertulis seperti sumber data buku, dan dokumendokumen dari pihak yang terkait yaitu Komisi Pemilihan Umum Kabupaten 


\section{Kajian: \\ Pembelajaran PPKn}

Labuhanbatu dan Badan Pusat Statistik Kabupaten Labuhanbatu.

\section{Teknik Pengumpulan Data}

1. Wawancara

Wawancara yang digunakan dalam penelitian ini dengan mengajukan pertanyaan-pertanyan terstrukur karena dalam penelitian peneliti menggunakan pedoman wawancara yang telah disusun.

\section{Dokumentasi}

Dokumentasi

merupakan

pengumpulan data oleh peneliti dengan cara mengumpulkan dokumen-dokumen untuk membahas keterkaitan masalah yang diteliti.

\section{Teknik Analisis Data}

Analisis sata dalam penelitian ini melalui pendekatan deskriptif, peneliti memlih JOMAS Vol. 1 No. 1 Januari (2019) Hal : 1 - 6 jenis penelitian ini karena peneliti bermaksud untuk mendeskripsikan proses rekrutmen calon legislatif sesuai dengan data yang telah diperoleh dari hasil wawancara dan dokumentasi sehingga nantinya dapat disimpulkan dari berbagai masalah mengenai proses rekrutmen calon legislatif oleh partai politik di kabupaten labuhanbatu (studi kasus pdip, nasdem, pks, pan).

\section{Hasil Penelitian dan Pembahasan}

\section{a. Deskripsi Umum Lokasi Penelitian}

Adapun lokasi penelitian ini dilaksanakan beberapa Partai Politik yang ada di Kabupaten Labuhanbatu yaitu :
Partai Demokrasi Indonesia Perjuangan, Partai Nasional Demokrat, Partai Keadilan Sejahtera, Partai Amanat Nasional.

\section{b. Pembahasan Hasil Penelitian}

Dari data calon tetap yang peneliti peroleh dari masing-masing partai politik di Kabupaten Labuhanbatau diperoleh jumlah daftar calon tetap Partai Demokrasi Indonesia Pejuangan sebanyak 45, Partai Nasional Demokrat Sebanyak 45, Partai Keadilan Sejahtera 40 dan Partai Amanat Nasional sebanyak 40 .

Jadi dapat disimpulkan bahwa masing-masing partai politk mempunyai calon tetap legislatifnya berdasarkan jumlah ketentuan dari partai itu sendiri.

\section{Kesimpulan dan Saran}

\section{A. Kesimpulan}

Data hasil Penelitian yang telah dilakukan dapat disimpulkan bahwa :

Proses rekrutmen calon legislatif oleh partai politik di Kabupaten Labuhanbatu pada pemilu 17 April 2019 (studi kasus PDIP, NASDEM, PKS, PAN) memiliki persamaan dalam proses rekrutmen yang dilakukan oleh masing-masing partai politik dan proses rekrutmen yang dilakukan melalui rekrutmen secara terbuka. Bentuk pelaksanaan syarat rekrutmen Pada pemilu 17 April 2019 yang dilakukan oleh masing-masing partai mengacu dalam ketentuan Peraturan Komisi Pemilihan Umum Nomor 20 Tahun 2018, namun ada ketentuan khusus yang dimiliki oleh Partai Keadilan Sejahtera dalam merekrut 


\begin{abstract}
Kajian:
Pembelajaran PPKn

calon legislatif yaitu harus beragama islam, dan mengikuti pengajianpengajian. Sementara berdasarkan pendapat teori Garata (2007) dalam bukunya yang berjudul sosiologi politik terdapat 3 sifat rekrutmen politik yaitu top-down, bottom-up, bersifat campuran. Dimana masing-masing partai politik PDIP, NASDEM, PKS, PAN dalam merekrut calon legislatifnya menggunakan sifat rekrutmen bottom-up. Bentuk penetapan calon legislatif masing-masing partai politik memiliki perbedaan, Partai Demokrasi Indonesia Perjuangan (PDIP) dalam menentukan penetapan calon legislatif diutamakan dari struktural partai yang ada di peratutan partai demokrasi indonesia perjuangan nomor 25-A tahun 2018 pasal 28 ayat 1 ketua, sekretaris, bendahara wajib nomor 1, sedangkan NASDEM dalam penetapannya menentukannya dari loyalitas calon legislatif artinya bagaimana pengabdian ke partai politik, keaktifan di berbagai kegiatan dan loyalitas yang diprioritaskan pada nomor urut atas, sedangkan PKS menentukan berdasarkan kewenangan dari partai itu yang menentukan dilihat dari keaktifan selama di partai politik, dan PAN menentukan penetapan calon legislatif sesuai dengan hasil dari skoring yang di lakukan oleh KPPD (Komite Pemenangan Pemilu Daerah).
\end{abstract}

\section{B. Saran}

Dari hasil penelitian yang sudah dipaparkan oleh peneliti, maka saran yang dapat diberikan adalah sebagai berikut :
JOMAS Vol. 1 No. 1 Januari (2019)

Hal : $1-6$

\section{Internal}

1. Bagi peneliti sendiri untuk menambah wawasan ilmu pengetahuan tentang proses rekrutmen calon legislatif.

2. Bagi perguruan tinggi sebagai bentuk implementasi tri darma perguruan tinggi (pendidik, penelitian, pengabdian dalam melaksanakan penelitian).

3. Bagi peneliti berikut sebagai bahan referensi untuk usulan penelitian.

\section{Eksternal}

1. Kepada pihak penyelenggara Pemilu yaitu Komisi Pemilihan Umum harus lebih selektif lagi dalam membuat peraturan calon legislatif partai politik sehingga nantinya akan menghasilkan calon legislatif yang berkualitas.

2. Selanjutnya saran yang dapat diberikan untuk Partai Politik yaitu seluruh Partai Politik harus memiliki aturan atau pedoman tentang rekrutmen calon legislatif.

3. Saran yang dapat diberikan kepada masyarakat yaitu masyarakat lebih selektif dalam menetukan pilihan dengan melihat rekam jejak dan profil calon legislatif partai politik. 


\section{Kajian:}

Pembelajaran PPKn

\section{Daftar Pustaka}

\section{Buku}

[1] Budiardjo, Miriam. 2013. Dasar-

Dasar Ilmu Politik. Jakarta: PT. Gramedia Pustaka Utama

[2] Damsar, 2010 . Pengantar Sosiologi Politik : Kencana Prenada Media Group

[3] Darmadi, Hamid. 2011. Metode Penelitian Pendidikan. Bandung: Alfabeta

[4] Gatara, Said. 2007. Sosiologi Politik. Bandung: CV. Pustaka Setia

[5] Labolo, Muhadam. 2017. Partai Politik dan Sistem Pemilihan Umum di indonesia.: PT Rajagrafindo

[6] Meleong.J.Lexy. 2014. Metodologi Penelitian Kualitatif. Bandung: PT REMAJA ROSDAKARYA

[7] Rahman. 2007. Sistem Politik Indonesia .Yogyakarta: GRAHA ILMU

[8] Sugiyono. 2014. Metode Penelitian Pendidikan Kuantitatif Kualitatif dan R\&D. Bandung:Alfabeta
[9] Sugiyono. 2016. Metode Penelitian Kuantitatif, Kualitatif, dan $R \& D$. Bandung: Alfabeta

[10] Sugiyono. 2016. Memahami Penelitian Kualitatif. Bandung : Penerbit Alfabeta

[11] Surbakti, Ramlan. 2013. Memahami Ilmu Politik. Jakarta: CC Prima Grafika

\section{Undang-undang}

[12] Undang-undang. Republik Indonesia Nomor 2 Tahun 2011 tentang Partai Politik

[13] Peraturan Komisi Pemilihan Umum Nomor 20 Tahun 2018 tentang Pencalonan Anggota Dewan Perwakilan Rakyat, Dewan Perwakilan Rakyat Daerah Provinsi, dan Dewan Perwakilan Rakyat Daerah Kabupaten/Kota

\section{Jurnal}

[14] Rizki, Karunia, Dwi. 2017.

Pola Rekrutmen Partai Nasional Demokrat Pada Pencalonan Anggota Legislatif Tahun 2014 Kabupaten Jombang. Jurnal Politik Muda, Vol.6, No. 1 